\title{
Nutrient Composition of Mushroom: Pleurotus Ostreatus (Jacaum, ex. Fr. Kummer) grown on Different Agricultural Wastes
}

\author{
Patience C. Obinna-Echem ${ }^{1} \Varangle$ \\ Franklyn A. Chukunda ${ }^{2}$ \\ 'Department of Food Science and Technology, Rivers State University, Nkpolu Oroworukwo, Port Harcourt, Nigeria \\ Email:chisamupat@yahoo.com \\ ${ }^{2}$ Department of Forestry and Environment, Faculty of Agriculture, Rivers State University, Nkpolu Oroworukwo, Port \\ Harcourt, Nigeria \\ Email:onyifrank@yahoo.com
}

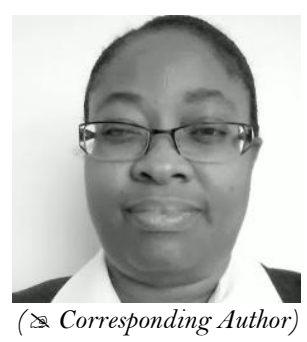

\begin{abstract}
The study evaluated the nutrient compositions of Pleurotus ostreatus (Jacaum, ex. Fr. Kummer) grown using different agricultural waste: sawdust, sugarcane (Sacharum officinarum) peels, plantain leaves and corn cobs. The proximate compositions of $P$. ostreatus fruit bodies varied significantly $(\mathrm{P} \leq 0.05)$. Matured fruit bodies of $P$. ostreatus harvested from sawdust and sugarcane peel substrates had significantly $(\mathrm{P} \leq 0.05)$ the highest content of moisture $(15.20 \%)$ and ash $(5.23 \%)$ respectively. The Corn cob substrates yielded P. ostreatus with significantly $(\mathrm{P} \leq 0.05)$ the highest amount of protein (9.38\%) and lipids (8.5\%); and lowest amount of carbohydrates $(51.76 \%)$. Crude fibre was found more in the fruit bodies of $P$. ostreatus harvested from sugarcane peel substrates $(8.23 \%)$ followed by corn cobs $(7.28 \%)$. The mineral content varied significantly $(\mathrm{P} \leq 0.05)$ from $0.43-0.90,0.12-0.30,9.20-14.6$, $7.30-13.0$ and $1.5-2.7 \mathrm{mg} / 100 \mathrm{~g}$ for iron, sodium, potassium, phosphorus and calcium respectively. $P$. ostreatus from sugarcane peels had significantly $(\mathrm{P} \leq 0.05)$ the highest mineral content except for calcium. Vitamin $\mathrm{C}$ content ranged from $1.3 \mathrm{mg} / 100 \mathrm{~g}$ for corn hob to $1.8 \mathrm{mg} / 100 \mathrm{~g}$ for sawdust. The study revealed that sugarcane peel and corn hob in terms of the proximate and mineral composition are better substrate for the growth of $P$. ostreatus. It is therefore recommended that these agricultural wastes should be used in the cultivation of $P$. ostreatus. Besides producing nutritious mushrooms, this will help to reduce the huge agricultural wastes within our environment that sometimes when not properly managed caused serious environmental pollution.
\end{abstract}

Keywords: Mushroom, Pleurotus ostreatus, Substrates, Proximate and mineral composition.

Citation | Patience C. Obinna-Echem; Franklyn A. Chukunda (2018). Nutrient Composition of Mushroom: Pleurotus Ostreatus (Jacaum, ex. Fr. Kummer) grown on Different Agricultural Wastes. and Food Sciences Research, 5(1): 1-5. History:

Received: 6 November 201

Revised: 10 January 2018

Accepted: 15 January 2018

Published: 17 January 2018

Licensed: This work is licensed under a Creative Commons

Attribution 3.0 License $(\boldsymbol{c c c}) \mathbf{E}$

Publisher:Asian Online Journal Publishing Group
Contribution/Acknowledgement: Both authors contributed to the conception and design of the study.

Funding: This study received no specific financial support.

Competing Interests: The authors declare that they have no conflict of interests.

Transparency: The authors confirm that the manuscript is an honest, accurate, and transparent account of the study was reported; that no vital features of the study have been omitted; and that any discrepancies from the study as planned have been explained.

Ethical: This study follows all ethical practices during writing.

\section{Contents}

1. Introduction

2. Materials and Methods

3. Results and Discussion

4. Conclusion ...

References 


\section{Introduction}

Mushroom is a macro-fungus with a distinctive fruiting body, which may be above ground (epigeous) or below ground (hypogeous) of sufficient size to be seen by the naked eye and to be picked up by hand [1]. All mushrooms belong to the kingdom Mycetae, a group distinct from animals, plants and bacteria. Most mushrooms belong to either Ascomycetes or Basidiomycetes. Like plants, fungi have a distinct cellular structure but they lack the most important feature of plants, the ability to use energy from the direct sunlight through chlorophyll [2]. Since mushrooms do not possess chlorophyll, they depend on other plant material the substrate for their food. They may simply be referred to as saprophytic, parasitic or symbiotic in nature [3].

Saprophytic mushrooms depend and grow in plant and animal remains and waste such as animal droppings, dead animals, twigs, fallen leaves, dead wood and stumps organic matter, [3, 4] thus forming the first menu in the food chain or food web. They secrete acids and enzymes which degrade plant and animal remains, breaks down large and insoluble molecules such as carbohydrates, lipids and protein into smaller molecules that can be absorbed $[5,6]$.

Parasitic mushroom depend on other organisms for their existence. They are either obligate or facultative. Parasitic mushroom such as honey mushroom destroys hectares of forest; and act as agents of habitat restoration. Honey mushroom (Arinilla bulbosa) covered 37 acres in Michigan forest and was estimated to be 1500 years old [5]. Facultative mushroom are weak parasitic mushroom found in dying host plant. The deaths of these are caused by other organisms, or environmental stress.

Symbiotic mushrooms live in harmony with other organism and they derive mutual benefit from each other. They are referred to as symbiotic or mutualistic mushroom. The hypha/mycelium releases or delivers salts, water and produces antibodies to protect the host plant from pathogens and other fungi while the mushroom benefits carbohydrates and other nutrients [7-9].

Commonly cultured mushrooms are saprophytic organisms that feed on dead plant materials. The part of the organism that we see and call a mushroom is really the fruiting body. Unseen is the mycelium-tiny threads that grow throughout the substrate deriving nutrients by breaking down organic materials. Some species of mushrooms can grow on a wide range of materials and others cannot. After the mycelium has grown throughout the substrate, and when its specific requirements are met, the mushroom will fruit [5].

Pleurotus ostreatus (Jacaum, ex. Fr. Kummer) is one among the 40 known species of the genus Pleurotus, they are commonly referred to as "oyster mushroom", grow widely in tropical and subtropical areas and easily artificially cultivated [10]. It is a facultative parasitic mushroom and commonly found in dying oak and cotton [11]. P. ostreatus has a broad, fan or oyster- shared cap spanning 5 to $25 \mathrm{~cm}$ natural specimens range from white to grey or tan to dark-brown; the margin is inrolled when young and smooth often somewhat lobed and wavy. P. ostreatus is popularly consumed all over the world due to their taste, flavor, high nutritional values and medicinal properties [10]. They provide many of the nutritional attribute commonly found in meat, beans, grains or other produce [12]. Mushrooms are rich sources of protein $[12,13]$ ash, lipid, crude fibre, and carbohydrate, minerals $(\mathrm{Ca}, \mathrm{Mg}$, $\mathrm{Na}, \mathrm{P}, \mathrm{K}, \mathrm{S}, \mathrm{Mn}$ and $\mathrm{Fe}$ ). Mushroom are good sources of vitamins like riboflavin, biotin and thiamine Chang and Buswell [14]. Buigut [15] reported that good number of essential amino acids and water soluble vitamins are present in most edible mushrooms. The nutritional and several medicinal properties of mushroom of the genus Pleurotus has been reviewed by some authors $[10,16]$. Some of the medicinal properties include antitumour a property associated to the presence of polysaccharides [17] antigenotoxic and bio-antimitagenic acidity [18] antihypertensive and anti-hyperglycaemic activities [19]. Pleurotus tuber-regium is a common species in southern part of Nigeria and it is very useful to cure headache, stomach ailments, colds and fever [20].

Mushroom has the ability to biodegrade organic matter and bioaccumulate potential nutrient essential for human wellbeing. Hence the cultivation of $P$. ostreatus using different agricultural wastes such as sawdust, sugarcane (Sacharum officinarum) peels, Plantain leaves and Corn cobs as substrate will be relevant in the reduction of the huge amount of these wastes. This may provide a partial solution to the nation's waste management problems and the pollution challenges around the environment. In addition to the nutritional benefit that would be derived from the consumption of the cultivated mushroom. This study was therefore aimed at using different agricultural wastes to cultivate $P$. ostreatus and determine the proximate and mineral compositions of $P$.ostreatus fruit bodies from the different agricultural wastes.

\section{Materials and Methods}

\subsection{Study Site}

The study was carried out at the laboratory of Forestry and Environment and Food Science and Technology, Rivers State University, Nkpolu Oroworukwo, Port Harcourt.

\subsection{Source of Spawn}

Pleurotus ostreatus spawn used for the production was obtained from mushroom farm Dilomat Nigeria Limited located in Rivers State University, Nkpolu Oroworukwo, Port Harcourt.

\subsection{Collection and Preparation of Substrates}

The sawdust residues were collected from the local wood industry at Elabuchi Port Harcourt. Sugarcane (Sacharum officinarum) peels and corn cobs were collected from sugarcane sellers' dump and corn sellers at Ogbunabali Port Harcourt, plantain leaves were also collected from plantain plantations at Ogbunabali. The substrates were prepared as described by Sales-Campos [21]. Briefly, the substrates were sun-dried, crushed and packed individually in black polypropylene bags and labelled.

Two hundred gram (200g) each of the substrate was humidified with $50 \%$ of water and the $\mathrm{pH}$ of 6.5 maintained using $5 \mathrm{~g}$ of calcium carbonate $\left(\mathrm{CaCo}_{3}\right)$ in relation to the dry sample weight of the substrates [22]. 


\subsection{Pasteurization and Inoculation}

The substrates were sterilized using autoclave at $121^{\circ} \mathrm{C}$ at $15 \mathrm{lbs}$ pressure for 15 munities to kill microbes or contaminates associated with the substrates. After inoculation in aseptic conditions, incubation was performed inside a humid chamber for one month at the temperature of $28 \pm 2^{\circ} \mathrm{C}$ and relative humidity of $85-90 \%$. Water was sprinkled regularly until primordial emergence [23, 24].

\subsection{Proximate Analysis}

The proximate compositions of the mushroom from the different substrates were analyzed using the standard analytical methods [25]. Moisture was determined by drying at $80^{\circ} \mathrm{C}$ to a constant weight in an air oven (Sanyo Gallenkamp, Weiss Technik, West Midlands, UK). Ash was determined gravimetrically in a muffle furnace (Sanyo Gallenkamp, Weiss Technik, West Midlands, UK) at $550^{\circ} \mathrm{C}$ for $6 \mathrm{~h}$. Determination of protein was by Kjeldahl method. After distillation and titration, the nitrogen was corrected using a factor of 4.38 for mushrooms [1]. Lipids were estimated by exhaustive extraction of $2 \mathrm{~g}$ of sample with petroleum ether in a rapid Soxhlet extraction apparatus (Gerhardt, Bonn, Germany). Crude fibre was obtained as the difference from the weight of ash subtracted from the increase of weight on the paper due to the insoluble material after the acid hydrolysis of the fat free samples and the filtration into ashless filter paper. Carbohydrate was determined by difference.

\subsection{Mineral Assay}

The atomic absorption method was employed for mineral element assay. Mineral element of Pleurotus ostreatus was determined by preparing solutions of their ashes. The quantitative measurement of each element: iron, magnesium, sodium, calcium phosphorus and potassium using GBC Avanta Ver 2.02 Atomic Absorption Spectrophotometer (Japan). Phosphorus was determined on the ash solution using the molybdenum blue method [25].

\subsection{Vitamin C Determination}

The vitamin $\mathrm{C}$ content of the Pleurotus ostreatus mushrooms was determined using standard analytical methods [25]. Briefly, $10 \mathrm{ml}$ of the prepared sample in a $50 \mathrm{ml}$ conical flask was titrated against 2, $6-$ Dichlorophenol solution until a fiant pink colour persisted for 15 seconds.

\subsection{Experimental Design and Analysis of Data}

The experiment was conducted in a Completely Randomized Design (CRD); the treatment was replicated five times. Data were statistically analyzed using Duncan Multiple Range Test (DMRT) at a probability of $5 \%$.

\section{Results and Discussion}

\subsection{Proximate Composition of Pleurotus Ostreatus Grown on Different Agricultural Wastes}

The proximate compositions of mature fruit bodies of $P$. ostreatus grown on different agricultural substrates varied significantly $(\mathrm{P} \leq 0.05)$ as shown in Table 1. Moisture is required for the normal biochemical activities in living things and also plays a role in the keeping quality of the harvested plant. The moisture content of the mature fruit bodies of $P$. ostreatus harvested from the different agricultural substrates ranged from $11.03-14.21 \%$ for Plantain leaves and Sugarcane peels respectively. The moisture content in this study is lower than the report by Roy, et al. [12]. The variation may be dependent on various factors, such as harvesting time, maturation period, substrate and environmental conditions of growth and storage [26]. Giving the uniform condition of growth of $P$. ostreatus in this present study, the variation could be attributed to the substrate used.

Table-1. Proximate composition (\%) of Pleurotus ostreatus grown on different agricultural wastes

\begin{tabular}{l|l|l|l|l|l|l}
\hline \multicolumn{7}{c}{ Table-1. Proximate composition $(\%)$ of Pleurotus ostreatus grown on different agricultural wastes } \\
\hline $\begin{array}{l}\text { Agricultural } \\
\text { substrates }\end{array}$ & Moisture & Total Ash & Protein & Total lipids & Crude fibre & Total carbohydrate \\
\hline Plantain leaves & $11.03 \pm 0.18^{\mathrm{d}}$ & $2.85 \pm 0.15^{\mathrm{c}}$ & $17.82 \pm 3.05^{\mathrm{c}}$ & $5.8 \pm 0.05^{\mathrm{b}}$ & $14.25 \pm 0.20^{\mathrm{d}}$ & $59.28 \pm 0.60^{\mathrm{c}}$ \\
\hline Sawdust & $15.20 \pm 0.20^{\mathrm{a}}$ & $5.23 \pm 1.20^{\mathrm{a}}$ & $16.80 \pm 0.25^{\mathrm{d}}$ & $5.3 \pm 0.04^{\mathrm{c}}$ & $16.20 \pm 0.25^{\mathrm{c}}$ & $56.47 \pm 0.40^{\mathrm{d}}$ \\
\hline Sugarcane peels & $14.21 \pm 0.25^{\mathrm{b}}$ & $3.10 \pm 0.11^{\mathrm{b}}$ & $18.20 \pm 0.42^{\mathrm{b}}$ & $5.6 \pm 0.08^{\mathrm{c}}$ & $18.23 \pm 0.21^{\mathrm{a}}$ & $54.86 \pm 0.52^{\mathrm{b}}$ \\
\hline Corn cobs & $12.14 \pm 0.22^{\mathrm{c}}$ & $3.08 \pm 0.20^{\mathrm{b}}$ & $19.38 \pm 0.58^{\mathrm{a}}$ & $8.5 \pm 0.06^{\mathrm{a}}$ & $17.28 \pm 0.30^{\mathrm{b}}$ & $51.76 \pm 0.37^{\mathrm{a}}$ \\
\hline
\end{tabular}

Note: Mean values with the same superscript in the same column are not significantly $(\mathrm{P} \leq 0.05)$ different. $\mathrm{N}=5 \pm \mathrm{SD}$.

The amount of protein, lipids and carbohydrate in the mature fruit bodies of the $P$. ostreatus grown on different agricultural substrates were in the range of $19.38-16.80 \%, 8.5-5.3 \%$ and $51.76-59.28 \%$ respectively. The result showed that the different agricultural wastes produced $P$. ostreatus with high protein content but corn hob substrate had significantly the highest amount. This suggests that $P$. ostreatus can be a valuable source of protein for use in other products like incorporation into complementary foods. The carbohydrate content is in agreement with the report that Carbohydrates constitute the prevailing component of mushroom dry matter, usually about 50-60\% [10]. According to Kalac [27] the various carbohydrate compounds of mushrooms which include monosaccharide, their derivatives and oligosaccharides are important in the proper functioning of the alimentary tract.

The lipid content varied from $5.3 \%$ for P. ostreatus harvested from sawdust to $8.5 \%$ for corn hob. The low lipid content confirms the report that mushrooms are generally low in oil and fat, although they may contain some essential fatty acids and can be recommended as good supplements for patients with cardiac problems [10, 28]. Muhammad, et al. [29] reported that protein, and fat content of various Pleurotus species was enhanced by different agro wastes used for the cultivation. Matured fruit bodies of $P$. ostreatus harvested from sugarcane peel substrates had significantly $(\mathrm{P} \leq 0.05)$ the highest content of ash (5.23\%). Ash is an indication of mineral component. The high percentage of protein, carbohydrate, crude fibre moisture in the mushroom fruit bodies cultivated on different substrates conforms to the report of Chukunda, et al. [30] and Ukoima, et al. [31]. 
Table-2. Mineral and Vitamin c Compositions of Pleurotus ostreatus Grown on Different Agricultural Wastes

\begin{tabular}{|c|c|c|c|c|c|c|}
\hline \multirow[b]{2}{*}{ Agricultural substrates } & \multicolumn{5}{|c|}{ Mineral (mg/100g dry weight basis) } & \multirow[b]{2}{*}{ Vitamin $\mathrm{C}$} \\
\hline & $\begin{array}{l}\text { Iron } \\
(\mathrm{Fe})\end{array}$ & $\begin{array}{l}\text { Sodium } \\
(\mathrm{Na})\end{array}$ & $\begin{array}{l}\text { Potassium } \\
(\mathrm{K})\end{array}$ & $\begin{array}{l}\text { Phosphorus } \\
\text { (P) }\end{array}$ & $\begin{array}{l}\text { Calcium } \\
(\mathrm{Ca})\end{array}$ & \\
\hline Plantain leaves & $0.43 \pm 0.01^{\mathrm{c}}$ & $0.12 \pm 0.02^{b}$ & $9.20 \pm 0.02^{\mathrm{c}}$ & $7.30 \pm 0.04^{c}$ & $2.7 \pm 0.02^{\mathrm{a}}$ & $1.6 \pm 0.03$ \\
\hline Sawdust & $0.65 \pm 0.02^{\mathrm{b}}$ & $0.22 \pm 0.01^{\mathrm{a}}$ & $12.6 \pm 0.04^{\mathrm{b}}$ & $10.8 \pm 0.03^{b}$ & $1.5 \pm 0.03^{\mathrm{b}}$ & $1.8 \pm 0.04$ \\
\hline Sugarcane peels & $0.90 \pm 0.04^{\mathrm{a}}$ & $0.30 \pm 0.03^{\mathrm{a}}$ & $14.6 \pm 0.05^{\mathrm{a}}$ & $13.0 \pm 0.05^{\mathrm{a}}$ & $1.7 \pm 0.04^{b}$ & $1.5 \pm 0.01$ \\
\hline Corn cobs & $0.85 \pm 0.03^{a}$ & $0.25 \pm 0.01^{\mathrm{a}}$ & $12.3 \pm 0.04^{\mathrm{b}}$ & $10.5 \pm 0.04^{b}$ & $1.2 \pm 0.04^{\mathrm{b}}$ & $1.3 \pm 0.01$ \\
\hline
\end{tabular}

\subsection{Mineral and Vitamin C Composition of Pleurotus Ostreatus Grown on Different Agricultural Waste}

The results of mineral composition of Pleurotus ostreatus grown in different substrates showed significant differences $(\mathrm{P} \leq 0.05)$ among the various substrates (Table 2). Sodium, potassium, phosphorus, calcium, and iron found in the fruit bodies of $P$. ostreatus were in the range of $0.12-0.30,9.20-14.6,7.30-13.0,1.2-2.7$ and $0.43-0.85 \mathrm{mg} / 100 \mathrm{~g}$ respectively. Mature fruit bodies from sugarcane substrate had significantly $(\mathrm{P} \leq 0.05)$ the highest amount of minerals followed by those of the corn hobs except for calcium. Fruit bodies from plantain leaves substrate was significantly $(\mathrm{P} \leq 0.05)$ the highest in calcium content. The rich minerals found could be attributed to the composition of the substrate and the ability of the mushroom to utilize these components from the substrates. The sodium content of the mature fruit bodies of P. ostreatus was lower than the report of Roy, et al. [12]. According to Chang and Quimio [19] low sodium content in mushrooms makes them ideal for persons with heart and kidney ailments. It has been reported that the proximate and mineral composition of edible mushroom were found to be significant for human consumption [13, 32, 33 ].

\section{Conclusion}

Research on conversion of agro-industrial wastes into some other useful forms is on-going and mushroom is said to be the most important bioconversion product. In this study: the different agricultural wastes (sawdust, sugarcane (Sacharum officinarum) peels, plantain leaves and Corn cobs) used to cultivate $P$. ostreatus produced mature fruit bodies with appreciable amount of nutrients. Sugarcane peel and corn hob in terms of the proximate and mineral composition are better substrate for the growth of $P$. ostreatus. Besides producing nutritious mushrooms, there is an added value in converting these agricultural wastes into foods and feeds. This will help proofer solution to environmental pollution problems created by unmanaged agro-industrial wastes around Port Harcourt Metropolis.

\section{References}

[1] P. G. Miles and S. T. Chang, Mushroom biology: Concise basics and current developments. Singapore: World Scientific Publishing Company, 1997.

[2] H. K. M. Chan, "Consumption of edible mushrooms in Hong Kong," Mushroom Newsletter for the Tropics, vol. 1, pp. 5-10, 1981. View at Google Scholar

[3] F. N. Emuh, "Bioremediation potenials of white rot fungi in the reclamation of crude oil polluted soil," Ph.D. Thesis submitted to Graduate School, Delta State University, Abraka, Nigeria, 2009.

[4] P. Oei, Mushroom cultivation with special emphasis on appropriate techniques for developing countries. Leiden, Netherlands: Tool Publication, 1996.

[5] P. Stamets, "Can mushrooms help save the world?. Explore," Journal of Science and Healing, vol. 2, pp. 152-161, 2006. View at Google Scholar | View at Publisher

[6] C. J. Alexopoulous and C. W. Mims, Introductory mycology. New York: John Wiley and Inc, 2003.

[7] F. N. Emuh, "Mushroom as a purifier of crude oil polluted soil," International Journal of Science and Nature, vol. 1, pp. 127-132, 2010. View at Google Scholar

[8] P. Oei and M. Maas, Mushroom cultivation, appropriate technology for mushroom growers, 3rd ed. Leiden, Netherland: Backhughs Publishers, 2003.

[9] N.R.C.M. National Research Centre for Mushroom, Transfer in mushroom biotechnology In Rai, R.D. Upadhyay, R. C. and Sharma, S. R. (Ed). India: Solan (HP), 2005.

[10] K. Deepalakshmi and S. Mirunalini, "Pleurotus ostreatus: An oyster mushroom with nutritional and medicinal properties," Journal of Biochemical Technology, vol. 5, pp. 718-726, 2014. View at Google Scholar

[11] F. R. Alofe, E. A. Odu, and H. C. Illoh, "Mushrooms, man and nature, edible wild mushrooms on decaying wood in Obafemi Awolowo university campus," Nigerian Fields, vol. 63, pp. 3-18, 1998. View at Google Scholar

[12] D. N. Roy, A. K. Azad, F. Sultana, A. S. M. Anisuzzaman, and P. Khondkar, "Nutritional profile and mineral composition of two edible mushroom varieties consumed and cultivated in Bangladesh," Journal of Phytopharmacology, vol. 4, pp. 217-220, 2015. View at Google Scholar

[13] T. O. Adejunmo and O. B. Awosanya, "Proximate and mineral composition of four edible mushroom species in South Western Nigeria," African Journal of Biotechnology, vol. 4, pp. 1084-1088, 2005. View at Google Scholar

[14] S. T. Chang and J. A. Buswell, "Mushroom neuthceuticals," World Journal of Microbiology and Biotechnology, vol. 12, pp. 473-476, 1996. View at Google Scholar

[15] S. K. Buigut, "Mushroom production in sustainable small-scale farming system-opportunities and constraints: A survey of Uasin Gishu district," in Proceedings of the Holticulture Seminar on Sustainable Horticultural Production in the Tropics at Jomo Kenyatta University of Agriculture \& Technology, Juja, Kenya 3rd - 6th, 2002.

[16] M. A. Khan and M. Tania, "Nutritional and medicinal importance of pleurotus mushrooms: An overview," Food Review International, vol. 28, pp. 313-329, 2012. View at Google Scholar

[17] E. V. Crisan and A. Sands, Nutritional value of edible mushrooms. In: The biology and cultivation of edible mushrooms, Chang, S. T. E W. A. Hayes (Eds). New York: Academic Press, 1975.

[18] R. O. Alabi, "Mycology and Nigerian culture: Past, present and future," in Proceedings of 1st Conference on African Mycology; Mauritius, June 10-15, 1990, 1991, pp. 43-52.

[19] S. T. Chang and T. H. Quimio, Tropical mushrooms, biology, nature and cultivation Methods. Hong Kong: Chinese University Press, 1982.

[20] B. A. Oso, "Pleurotus tuber-regium from Nigeria," Mycologia, vol. 69, pp. 271-279, 1977. View at Google Scholar $\mid$ View at Publisher

[21] C. Sales-Campos, Aproveitamento de resIduos niadeireiros ecia agroindIstria regional para o cultivo de fungos comestiveis de ocorrèncianaregiao amazônica.f. Tese (Doutorado em Biotecnologia). Manaus: 1Jniversidade Federal do Ainazonas, 2008.

[22] J. A. Okhuoya and F. O. Okogbo, "Cultivation of pleurotus tuber-regium (Fr.) Singer on various farm wastes," in Proceeding of Oklahoma Academy of Science, 1990, pp. 1-3. 
[23] O. Fasidi and M. Kadiri, "Effect of sporophores maturity on chemical composition of Volvariella esculenta (Mass) Singer, a Nigerian edible mushroom," Die Nahrung, vol. 37, pp. 269-273, 1993. View at Google Scholar | View at Publisher

[24] F. A. Chukunda, S. A. Abere, and B. Nwondi, "Production of oyster mushroom (Pleurotus Ostreatus) in different agricultural substrates in Rivers State, Nigeria," International Journal of Agriculture, vol. 3, pp. 163-169, 2011.

[25] AOAC, Official methods of analysis of association of official analytical chemist, 19th ed. Washington DC, USA, 2012.

[26] D. Agrahar-Murugkar and G. Subbulakshmi, "Nutritional value of wild edible green leaves consumed by the Khasis of Meghalaya," Food Chemistry, vol. 89, pp. 599-603, 2005. View at Google Scholar $\mid$ View at Publisher

[27] P. Kalac, Chemical composition and nutritional values of European species of wild growing mushrooms. Mushrooms: Types, properties and nutrition: Nova Science Publishers Inc, 2012.

[28] I. C. Okwulehie, I. A. Okwujiako, and H. O. Edeoga, "Proximate, macro element and vitamin composition of the fruit bodies of pleurotus ostreatus (var. Florida) Eger grown on different substrate and substrates supplementation," Global Science Books, vol. 2, pp. 184-188, 2008. View at Google Scholar

[29] A. Muhammad, S. Muhammad, A. Shabbier, and H. M. Asif, "Protein and fat contents of various pleurotus species raised on different waste materials," Pakistan Journal of Agricultural Science, vol. 44, pp. 140 - 143, 2007. View at Google Scholar

[30] F. A. Chukunda, H. N. Ukoima, and E. Osele, "Identification and determination of nutritional compositions of some wild mushrooms collected from Oduoha Emohua forest," Asian Journal of Science and Technology, vol. 4, pp. 3890-3894, 2017.

[31] H. N. Ukoima, L. O. Ogbonnaya, G. E. Arikpo, and F. N. Ikpe, "Cultivation of mushrooms (Volvariella Volvacea) on vgrious farm waste in Obubra local government of Cross River State, Nigeria," Pakistan Journal of Nutrition, vol. 8, pp. 1059-1065, 2009c.

[32] U. R. Onyeizu, M. C. Nwoko, F. A. Chukunda, and H. N. Ukoima, "Nutritional and Bioactive compounds evaluation of pleurotus pulmonarius (Freis) Quell fruit bodies grown on different wood logs," International Journal Information Research and Review, vol. 4, pp. 168-172, 2017.

[33] Akindahunsi and F. L. Oyetayo, "Nutrient and antinutruent distribution of edible mushroom, pleurotus tuber regium (Fries) singer," LWT-Food Science and Technology, vol. 39, pp. 548-553, 2006. View at Google Scholar | View at Publisher 